\title{
A PAISAGEM NO MUNDO DA CRIANÇA: CONSIDERAÇÕES ACERCA DO ENSINO DE GEOGRAFIA NAS SÉRIES INICIAIS DO ENSINO FUNDAMENTAL
}

\section{Landscape in child world: considerations about the teaching Geography of Primary School}

Carolina Machado Rocha Busch Pereira Professora Adjunta do curso de Geografia da U. F. do Tocantins (Campus de Porto Nacional) carolinamachado@uft.edu.br

Jane Nunes Mascarenhas Graduanda em Geografia na U. F. do Tocantins (Campus Porto Nacional) mascarenhasnunesjane@ hotmail.com

Artigo recebido em 06/03/2016 e aceito para publicação em 28/12/2016

DOI: 10.12957/tamoios.2016.21889

\section{Resumo}

A presente pesquisa versa sobre a importância da paisagem no mundo da criança. Tem como objetivo refletir sobre a importância do desenho no ensino de Geografia nas séries iniciais para compreensão da paisagem. Para o desenvolvimento da pesquisa foram realizadas oficinas com o propósito de compreender a interpretação que a paisagem assume no mundo da criança, em uma representação através do desenho. A pesquisa foi realizada com alunos da faixa etários de 6 a 12 anos matriculadosno $1^{\circ}$ e $5^{\circ}$ ano do ensino fundamental na cidade de Porto Nacional, TO.

Palavras-chave: Ensino de Geografia, Paisagem, Séries Iniciais.

\begin{abstract}
This researchfocuses on theimportance oflandscapein the worldof the child.Aims to reflecton the importance ofdesignin the teaching ofgeographyin the early gradestounderstandingthe landscape. During thesearcha workshopwith thepurpose of understandingwhat interpretationassumesthat the landscapein the worldof the child, ina representationthrough drawingwas developed. The survey was conductedwithstudents from theagegroup of 6 to12 yearsenrolledin the 1stand5th yearof primary school in Porto Nacional, TO.
\end{abstract}

Keywords: Teaching Geography, Landscape, Primary School. 


\section{Consideracões Iniciais}

As economias e o mundo são movidos por novas atividades na contemporaneidade e a escola, assim como a educação tem sido constantemente afetada por tais mudanças. As mudanças reverberam no espaço novas paisagens e novas relações, principalmente ocasionadas pela aceleração digital e informacional. Alteraram-se também as relações sociais, familiares e outras dimensões da vida que modificaram não somente a forma, mas, sobretudo o conteúdo. A concepção de família que hoje adotamos não é a mesma que adotávamos na década de 1960 do século passado, assim como a escola também foi com o passar do tempo modificando as suas estrutura e relações para adequar-se às novas transformações que as relações sociais impuseram.

Diante de novas formas e conteúdos, resultado da combinação de elementos do passado e do presente, as espacialidades contemporâneas nos convidam a pensar a criança que temos hoje nas escolas diante do desafio do mundo. Desta forma algumas questões norteiam a presente reflexão: quais as características do mundo hoje? E quais as características das crianças na atualidade? Essas perguntas são comumente feitas pelos profissionais da educação para pensar os conteúdos, desafios, objetivos e características da educação na escola da atualidade.

Considerando que o trabalho possui o foco no ensino da Geografia, outra questão pertinente que problematiza a pesquisa é sobre as práticas da Geografia escolar: quais são os conteúdos ensinados pela alfabetização geográfica nas séries iniciais? De que maneira é abordado o ensino da paisagem nas séries iniciais?

Nesse sentido o presente trabalho se objetiva a refletir sobre a importância do desenho no ensino de Geografia nas séries iniciais para compreensão da paisagem. Uma vez que entendemos que a alfabetização geográfica ocorre concomitantemente com a alfabetização e o letramento, e a prática do desenho se faz presente no processo, e trabalhar o ensino de Geografia e mais especificamente o ensino da paisagem com o desenho pode fortalecer a aprendizagem e, sobretudo reforçar a espacialidade dos fenômenos geográficos. Quando a criança desenha, ela representa o mundo e os elementos que concebe do mundo e a partir do desenho podem-se construir práticas de aprendizagem geográfica a partir da noção de paisagem e espacialidade.

Nas séries iniciais, o processo de aprendizagem é permeado pelo questionamento acerca do olhar das crianças para a escola, para o mundo, para a família, para a sala de aula, assim, geralmente, repercuti na aprendizagem a percepção da criança e seu contato com as diferentes escalas.

O presente artigo busca apresentar uma reflexão acerca do tema paisagem no mundo da criança procurando evidenciar a importância do desenho no ensino de Geografia nas séries iniciais e sua contribuição para a compreensão da paisagem visual e sonora.

\section{$\underline{\text { O Ensino de Geografia nas Séries Iniciais: perspectivas e olhares }}$}

Para iniciar a reflexão proposta pelo trabalho a questão que orienta a pesquisa está amparada no debate sobre qual a importância da Geografia nas séries iniciais e como este processo de aprendizagem contribui para o desenvolvimento da criança. A princípio se faz necessário compreender o papel da Geografia nas séries iniciais do ensino fundamental que segundo os Parâmetros Curriculares Nacionais prevê que:

A Geografia tem por objetivo estudar as relações entre o processo histórico na formação das sociedades humanas e o funcionamento da natureza por meio da leitura do lugar, do território, a partir de sua paisagem. Na busca dessa abordagem 
relacional, trabalha com diferentes noções espaciais e temporais, bem como com os fenômenos sociais, culturais e naturais característicos de cada paisagem, para permitir uma compreensão processual e dinâmica de sua constituição, para identificar e relacionar aquilo que na paisagem representa as heranças das sucessivas relações no tempo entre a sociedade e a natureza em sua interação. (BRASIL/MEC, 1998, p. 26).

Neste sentido, o lugar da Geografia nas series iniciais segundo Callai (2005, p. 229) é "aprender a pensar o espaço. E, para isso, é necessário aprender a ler o espaço." Segundo Castellar (apud CALLAI, 2005, p. 229) ler o espaço:

significa criar condições para que a criança leia o espaço vivido e fazer essa leitura demanda uma série de condições, que podem ser resumidas na necessidade de se realizar uma alfabetização cartográfica, e esse é um processo que se inicia quando a criança reconhece os lugares, conseguindo identificar as paisagens. (CASTELLAR apud CALLAI, 2005, p. 229)

Para tanto, a criança precisa saber olhar, observar, descrever, registrar e analisar. Atividades que são desenvolvidas e aperfeiçoadas pela escola durante o processo de aprendizagem.

A criança deve conhecer o espaço geográfico em que vive, e é através do estimulo dado pelo professor que, irá despertar a sua curiosidade. Neste pensamento entende-se que o professor é um importante intermediador de conhecimento, através de suas práticas educativas.

O professor, as suas concepções de educação e de geografia, é que podem fazer a diferença. E é a interlocução dos saberes que pode permitir esse avanço. $O$ conhecimento geográfico produzido na escola pode ser o explicitamento do diálogo entre a interioridade dos indivíduos e a exterioridade das condições do espaço geográfico que os condiciona. (CALLAI, 2005, p. 231).

O ensino de Geografia nas séries iniciais exerce grande importância nos anos iniciais dos alunos, por isso, quando se busca o estimulo através do conhecimento prático, o aprendizado de torna mais fácil e interessante. Assim de acordo com os Parâmetros Curriculares Nacionais:

\begin{abstract}
A observação, descrição, analogia e síntese são procedimentos importantes e podem ser praticados para que os alunos possam aprender a explicar, compreender e representar os processos de construção dos diferentes tipos de paisagens, territórios e lugares. Isso não significa que os procedimentos tenham um fim em si mesmos: observar, descrever e comparar servem para construir noções, espacializar os fenômenos, levantar problemas e compreender as soluções propostas. Enfim, para conhecer e começar a operar os conhecimentos que a Geografia, como ciência, produz. (BRASIL/MEC, 1998, p. 30).
\end{abstract}

Contudo, é importante que a criança perceba através do seu dia-a-dia, como a Geografia está presente em seu cotidiano e aprenda a contextualizar este espaço vivido, para assim, tornar o entendimento mais fácil e interessante.Neste sentido, é importante entender que a criança passa por vários estágios.

Sobre o desenvolvimento cognitivo Ries (apud CARMO; BOER, 2014, p. 3) afirma que:

[...] para Piaget o desenvolvimento cognitivo é um processo que se realiza em todo o ser humano e tem um caráter seqüencial. Assim, ocorre uma série de estágios, sendo 
que através destes desenvolvimentos vai sendo construída a estrutura seguinte que será sempre mais complexa e abrangente que a anterior. (RIES apud CARMO; BOER, 2014, p. 3)

Piaget (2002) procurou estudar os processos de ampliação do conhecimento na formação de pensamento da criança, que segundo ele ocorre de forma sequencial. As relações estabelecidas entre o sujeito e o meio é que vão estruturar a troca de aprendizagem.

A assimilação e a acomodação são, portanto, os dois pólos de uma interação entre o organismo e o meio que é a condição para qualquer funcionamento biológico e intelectual e uma tal interação supõe, já de inicio, um equilíbrio entre as duas tendências dos polos contrários. (PIAGET, 2002, p. 360).

A presente pesquisa foi realizada com crianças que se encontram na fase denominada por Piaget (2002) de operacional-concreto. Segundo Goulart (apud SOUZA; WECHSLER, 2014, p. 141) "O período operatório concreto ocorre aproximadamente na faixa etária dos sete aos onze anos, e é caracterizado como sendo uma fase de transição entre a ação e as estruturas lógicas mais gerais". Assim, como coloca Faria (2001, p. 48):

\begin{abstract}
A tarefa cognitiva imposta à criança (...) no período operacional concreto, é dominar as operações. Onde (...) a operação é uma ação interiorizada, que se torna reversível para se coordenar com outras na forma de estruturas operatórias (...) formando sistemas de operações, responsáveis pelo aparecimento de noções como substância, peso, volume, espaço, série, classe, número etc., definidas ou expressas, de agora em diante, através da linguagem. (FARIA, 2001, p. 48)
\end{abstract}

Neste período a criança começa a "dominar as operações"a criança já tem uma organização mental integrada, onde, desenvolve a estruturação do pensamento, ampliando cada vez mais a linguagem e a vontade sobre o que quer.

Porém, segundo Ferraciolli (apud SOUZA; WECHSLER, 2014, p. 136):

É importante ressaltar que as idades apresentadas para cada estágio são apenas médias. Assim sendo, podem variar de um sujeito para outro, de acordo com seu meio social e o grau de inteligência, mas a ordem dos estágios é a mesma para todos os indivíduos. (FERRACIOLLI apud SOUZA; WECHSLER, 2014, p. 136)

A aprendizagem é construída gradativamente e as idades são apresentadas por médias. Sendo assim, cada criança irá absorver o conteúdo de maneira diferente, dependendo da forma em que, o ambiente social vai intervir em seu conhecimento e no grau de construção de cada um.

\title{
$\underline{\text { A Paisagem no Mundo da Crianca }}$
}

Com o passar dos anos, o processo de ensino/aprendizagem passou por várias mudanças, em uma busca constante por melhorias quanto à educação.

A contextualização com a realidade pode trazer uma clareza sobre a informação que é passada, com isso, o resultado que se espera, pode ser construído de maneira positiva. Cada criança tem em seu interior uma compreensão ao seu entender, sobre o mundo que a cerca. Para tanto, é necessário que se estimule o despertar da criança nas séries iniciais, quanto ao seu entendimento sobre paisagem. E buscar entender, através do desenho, que significado a paisagem assume no mundo de cada criança. 
Os PCN's nos mostram que, há diversas possibilidades de interpretação quanto a paisagem, onde,no convívio, no dia-a-dia a criança venha a construir um imaginário cheio de representações.

As pessoas têm a liberdade de dar significados diferentes para as coisas, e no seu cotidiano elas convivem com esses significados. Uma paisagem, seja de uma rua, de um bairro, ou de uma cidade, além de representar uma dimensão concreta e matéria do mundo, está impregnada de significados que nascem da percepção que se tem dela. No seu cotidiano os alunos convivem de forma imediata com essas representações e significados que são construídos no imaginário social. [...] Assim, falar do imaginário em Geografia é procurar compreender os espaços subjetivos, os mapas mentais que se constroem para orientar as pessoas no mundo (...) $\mathrm{O}$ imaginário não deve ser aqui compreendido como o mundo do devaneio, mas o das representações (...) Nesse sentido, acreditamos que trabalhar com o imaginário do aluno no estudo do espaço é facilitar a interlocução com ele e compreender o significado que as diferentes paisagens, lugares e coisas tem para ele. (BRASIL/MEC, 1998, p. 23).

O imaginário absorvido por cada criança assume uma interpretação de sua realidade. Na Geografia a busca para uma melhor compreensão da paisagem, pode ser também trabalhada por outros meios como, a literatura, o desenho, a fotografia, a música entre outros, porém, com um único objetivo, uma melhor interpretação/compreensão e construção de conhecimento.

\begin{abstract}
Ao pretender o estudo das paisagens, territórios, lugares e regiões, a Geografia tem buscado um trabalho interdisciplinar, lançando mão de outras fontes de informação. (...) com a literatura, por exemplo, tem sido redescoberta, proporcionando um trabalho que provoca interesse e curiosidade sobre a leitura desse espaço. É possível aprender geografia com a Literatura (...) também as produções musicais, a fotografia e até mesmo o cinema são fontes que podem ser utilizadas por professores e alunos para obter informações, comparar e inspirar-se para interpretar as paisagens e construir conhecimentos sobre o espaço geográfico. (...) A geografia trabalha com imagens, recorre a diferentes linguagens na busca de informações e como forma de expressar suas interpretações, hipóteses e conceitos. (BRASIL, 1998, p.33).
\end{abstract}

A Geografia é trabalhada de maneira interdisciplinar nas séries iniciais do ensino fundamental sobretudo a partir de conteúdos que corroboram para que a criança compreenda e interprete a paisagem. A paisagem é inicialmente apresentada a partir dos elementos visuais e coo expressão imagética do mundo, mas nem só de paisagem visual o processo de ensino e aprendizagem se materializa. Temos também a paisagem sonora que é uma forma de trazer a criança para um ambiente que está além do visível e que contribui sobremaneira para compor uma visão da paisagem mais orgânica e integrada. A percepção dos sons, de uma música, do barulho dos carros, na própria escola no seu entorno, pode ser um estimulo a trazer o aluno do mundo imaginário para uma interpretação da paisagem segundo Schafer (apud MALANSKI, 2011, p. 258) afirma:

a terminologia paisagem sonora se caracteriza pela unidade dos sons de um determinado lugar, englobando sons de natureza agradável ou desagradável (ruído), além de contribuir com a idéia de que o som de um lugar pode expressar a identidade de sua comunidade.

Conforme nos explica TORRES \& KOZEL (2010): 
[...] a paisagem sonora pode conter sons de diferentes naturezas, como por exemplo: os sons dos animais, os sons dos fenômenos da natureza (vento, chuva, trovões, mar, etc.), os sons advindos dos objetos construídos pelos seres humanos (meios de transporte, ferramentas de trabalho, aparelhos eletrodomésticos, etc.), os sons dos seres humanos (falas, sotaques, ato de caminhar ou correr, as músicas, etc.); entre outros. (TORRES \&KOZEL, 2010, p. 127)

De acordo com Torres e Kozel (2010, p. 127) “A paisagem sonora é cultural, pois reflete a identidade de um lugar e de seus habitantes".

A música pode ser um meio de interpretação, para que a criança das series iniciais do ensino fundamental, possa ser instigada a pensar. A música possui elementos que faz com que, a criança faça uma reflexão do que conhece sobre, o que entende em seu interior e assim consiga desenvolver a sua percepção sobre o não visível.

Dentre as várias linguagens que podem ser utilizadas para aproximar os conteúdos geográficos à realidade do aluno, temos a música, que além de transmitir uma idéia, resgata a emoção e a afetividade no ensino. (SILVA, 2013, p. 38).

A música aproxima o aluno com os conteúdos e traz incentivo para uma aula mais dinâmica e interessante. Ela faz com que a criança transmita o que sente, desse modo como coloca Silva (2013, p. 39):

A música enquanto ferramenta didática tem a capacidade de unir razão e emoção, enriquecendo dessa maneira o processo de ensino-aprendizagem, promovendo ressignificação, resgate da afetividade e valorização dos conteúdos de geografia.

Portanto, a música enquanto ferramenta didática nas series iniciais do ensino fundamental, ajuda no processo de ensino aprendizagem, pois, permite que, o aluno tenha uma construção de uma paisagem que não é visual, mas sim, sonora e se torne um incentivo para que a criança desenvolva uma habilidade que não é o da escrita, mas sim a representação visual através do desenho.

A representação da paisagem sonora através do desenho é uma maneira de levar o aluno a pensar e trazer do seu interior, o entendimento sobre o que ele deseja falar.

\section{$\underline{O}$ Conceito de Paisagem na Geografia Escolar}

Orientado pela compreensão da paisagem, a reflexão caminha na direção de compreender qual a importância dessa categoria, na formação da criança.

Segundo Mendonça e Venturi (apud SCHIER, 2003, p. 81)

as premissas históricas do conceito de paisagem, para a geografia, surgem por volta do século XV no renascimento, momento em que o homem, ao mesmo tempo em que começa a distanciar-se da natureza, adquire técnica suficiente para vê-la como algo passível de ser apropriado e transformado.

A paisagem para Tuan (apud HOLZER, 1997, p. 81-82) "é um campo que se estrutura na relação do eu com o outro, o reino onde ocorre a nossa história, onde encontramos as coisas, os outros e a nós mesmos". Neste sentido, a paisagem além do que se vê, está presente no nosso dia-a-dia, nas relações em que estamos, faz parte da história de cada um.

Segundo Santos (apud SERPA, 2013, p.3)

a paisagem resulta de um processo de acumulação, mas é, ao mesmo tempo contínua no espaço e no tempo, é una sem ser totalizante, é compósita, pois resulta sempre de 
uma mistura, um mosaico de tempos e objetos datados. A paisagem pressupõe também um conjunto de formas e funções em constante transformação, seus aspectos "visíveis", mas, por outro lado, as formas e as funções indicam a estrutura espacial, que é, em princípio, "invisível" e resulta sempre do "casamento" da paisagem com a sociedade.

Para fazer uma leitura da paisagem é necessária leitura da realidade das crianças, para que, haja uma troca de experiências entre os alunos, buscando na vivencia de ambos um melhor entendimento, de modo que percebam a paisagem local em que vivem e como cada um a vê, dessa forma, que consigam reconhecer e localizar as características da paisagem local comparando assim também com as outras.

Desse modo, levanta-se a questão, qual é a importância desta categoria de analise (paisagem), na formação da criança? Assim, devemos entender de que forma, a paisagem exerce influência quanto ao significado que expressa na construção e aprendizado das crianças nas séries iniciais. Segundo (CALLAI, 2005, p. 234) O importante é:

poder trabalhar, no momento da alfabetização, com a capacidade de ler o espaço,com o saber ler a aparência das paisagens e desenvolver a capacidade de ler os significados que elas expressam. Um lugar é sempre cheio de história e expressa/mostra o resultado das relações que se estabelecem entre as pessoas, os grupos e também das relações entre eles e a natureza.

Segundo Callai (2004, p.5) "Fazer a leitura da paisagem é portanto uma possibilidade para que seja lida a realidade, percebendo a história, o movimento, a mobilidade territorial, a seletividade espacial que é resultado do social". A autora destaca o quanto a leitura da paisagem pode ser importante ao aprendizado dos alunos nas séries iniciais do ensino fundamental e como a contextualização com a realidade pode ajudar no desenvolvimento da criança, pois, cada uma vê e analisa a paisagem de forma diferente, de acordo com o conhecimento e vivencia que possuem.

Contudo a paisagem está além do que se vê, do perceptível e concreto, está também no imaginário e no sentido que a interpretação feita por cada criança assume.

\title{
Materiais e Método
}

A operacionalização da pesquisa organizou-se por meio de consultas bibliográficas, documentais, principais fontes dos dados secundários. Para Gil (2010, p.29) "A pesquisa bibliográfica é elaborada com base em material já publicado. Tradicionalmente, esta modalidade de pesquisa inclui material impresso, como livros, revistas, jornais, teses, dissertações e anais de eventos científicos". Assim, primeiramente, levantaram-se referências bibliográficas e documentais sobre a temática.

A pesquisa foi realizada em duas partes: teórica e a prática. Na parte teórica foi desenvolvido o plano teórico e conceitual do trabalho. A parte prática da pesquisa foi realizada através da oficina geográfica musical onde os alunos escutaram a música "Herdeiros do Futuro" composta por Toquinho e Elifas Andreatto (1997) e interpretada por Leandro e Leonardo.

\section{Herdeiros do Futuro}

\author{
"A vida é uma grande amiga da gente, \\ Nos dá tudo de graça pra viver: \\ Sol e céu, luz e ar, \\ Rios e fontes, terra e mar.
}




\section{Somos os herdeiros do futuro \\ E pra esse futuro ser feliz \\ Vamos ter que cuidar \\ Bem desse país.}

Será que no futuro haverá flores?

Será que os peixes vão estar no mar?

Será que os arco-íris terão cores,

E os passarinhos vão poder voar?

Será que a terra vai seguir nos dando

O fruto, a folha, o caule e a raiz?

Será que a vida acaba encontrando

Um jeito bom da gente ser feliz?

\section{Vamos ter que cuidar}

Bem desse país"

A oficina foi realizada em duas turmas diferentes. Em cada sala a oficina teve duração de 1 (uma) hora. As turmas são do período vespertino, e o trabalho foi desenvolvido com 22 (vinte e dois) alunos do $1^{\circ}$ ano e 19 (dezenove) alunos do $5^{\circ}$ ano, em escola da rede pública do município de Porto Nacional, TO. Para a realização da oficina foram utilizados os seguintes materiais: Papel, lápis, borracha, giz de cera, lápis de cor, pen drive, aparelho de som e câmera digital. No total foram desenvolvidos 22 (vinte e dois) desenhos na turma de $1^{\circ}$ ano e 19 (dezenove) no $5^{\circ}$ ano.

Primeiramente foi feito uma apresentação quanto à pesquisa e seus objetivos. As fotografias a seguir mostram o encontro e apresentação, das oficinas para as turmas de $1^{\circ}$ e $5^{\circ}$ ano do Ensino Fundamental.

Figura 1: apresentação da oficina para a turma de $1^{\mathrm{o}}$ ano.

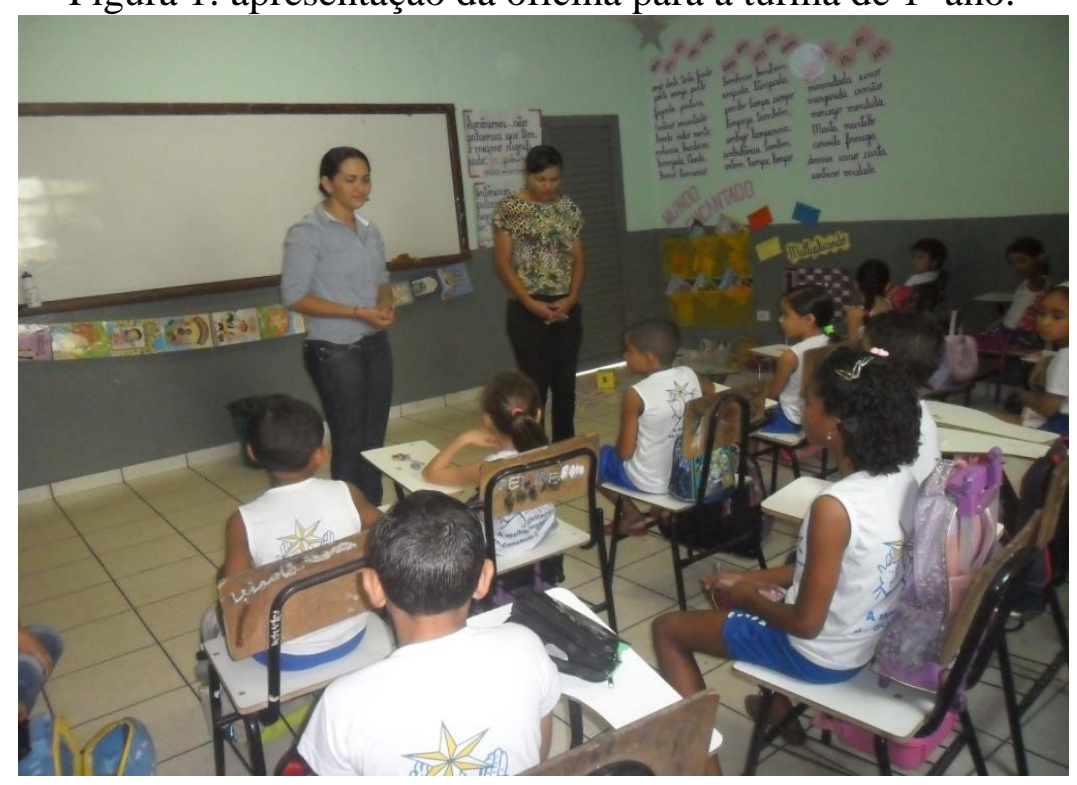

Após a apresentação, os alunos escutaram a música e foram convidados a criar desenhos que representassem a narrativa da canção e por tanto, esperava-se a representação de 
desenhos alegres e que indicassem o futuro na visão de cada criança. As fotografias a seguir mostram o desenvolvimento das oficinas.

Figura 2: Turma de $1^{\circ}$ ano (desenvolvimento da oficina)

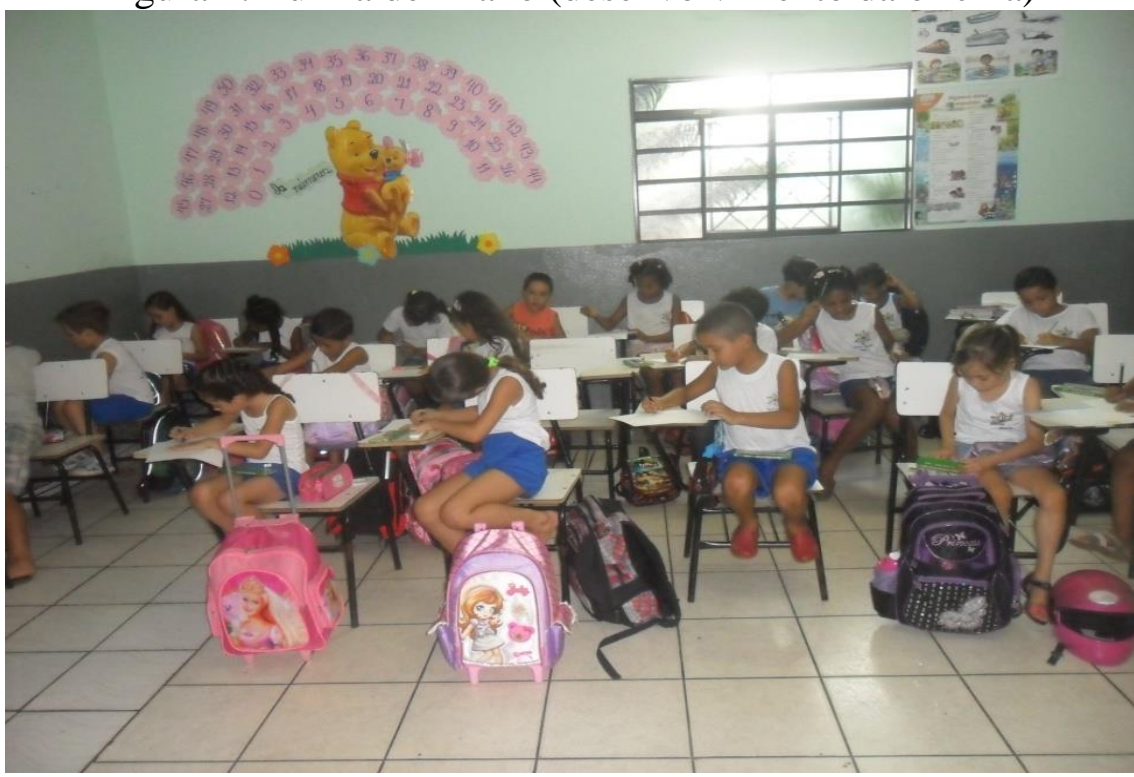

Figura 3: Turma de $5^{\circ}$ ano (desenvolvimento da oficina)

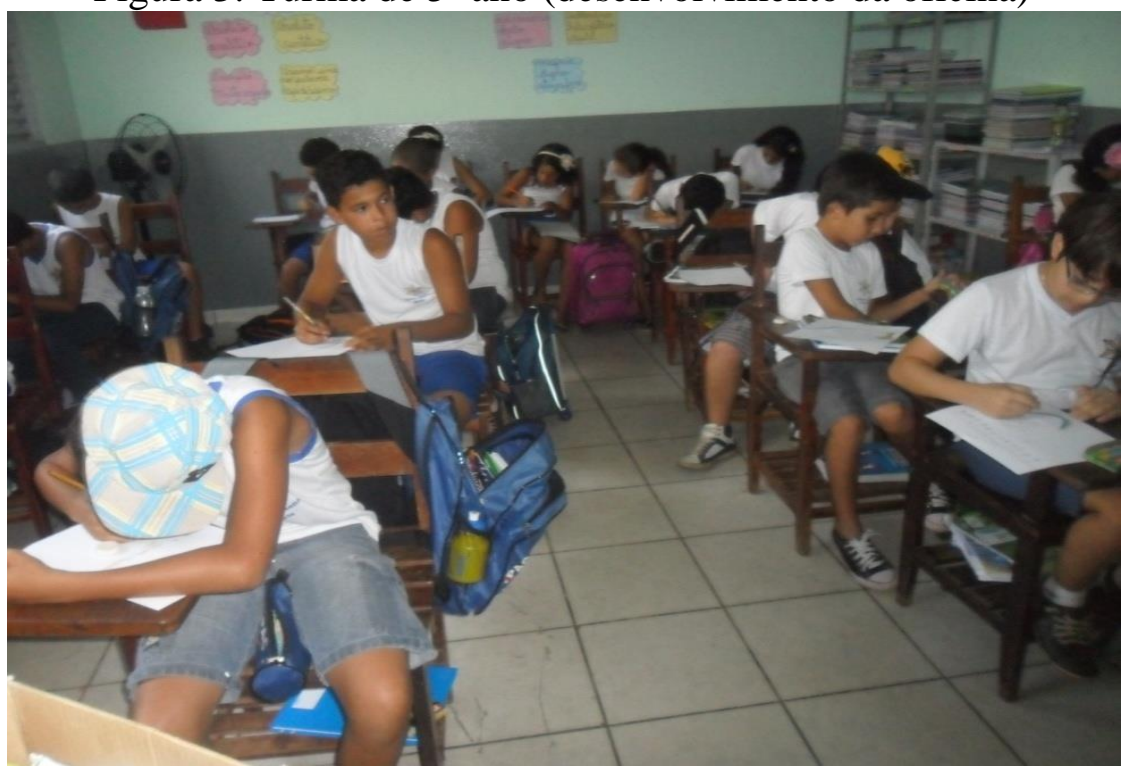

Dos 22 (vinte e dois) desenhos realizados no $1^{\circ}$ ano, foram selecionados para análise e discussão 10 (dez) desenhos, e dos 19 (dezenove) desenhos realizados no $5^{\circ}$ ano, foram selecionados para análise e discussão $10(\mathrm{dez})$ desenhos. O recorte deve-se fundamental ao numero expressivo de desenhos frente à limitação de espaço para análise que o artigo possui. Por esta razão foram selecionados uma amosta.

\section{$\underline{\text { Resultados e Discussão }}$}

De acordo com a música apresentada e os objetivos propostos, esperava-se encontrar, desenhos alegres e que indicassem um futuro harmônico na relação homem/natureza, onde o 
homem deveria estar presente nas representações dos desenhos, uma vez que é ele o "Herdeiro do Futuro".

Nossa pesquisa é qualitativa e apresenta um caminho que possibilita compreender os processos humanos pelo olhar dos sujeitos pesquisados, neste caso, as crianças. Assim, assumimos esta perspectiva de acordo com Santos (2016, p. 191)) que indica que o "investigador introduz-se no mundo das pessoas que pretende estudar, tenta conhecê-las, darse a conhecer e ganhar a sua confiança, elaborando um registro escrito e sistemático de tudo aquilo que ouve e observa".

Esse momento de inserção na escola permitiu observar o desenvolvimento das crianças a partir dos desenhos e das apropriações, conexões e interrelaçoes que as mesmas foram apresentando durante a oficina. A seguir, o desenho de J.A (Figura 4) que é um desenho alegre e rico em cores, ela traça uma linha de base, apresenta elementos naturais, tem a presença da natureza fortemente marcada, ela apresenta o elemento humano. Em contraposição com o desenho do M.A (Figura 5), que, apesar de apresentar um desenho bem organizado, não apresenta o homem, ele ainda não consegue fazer a relação da paisagem e do elemento humano. A paisagem para ele é formada só por elementos naturais como: árvores, rios, peixes, flores, sol, nuvens.

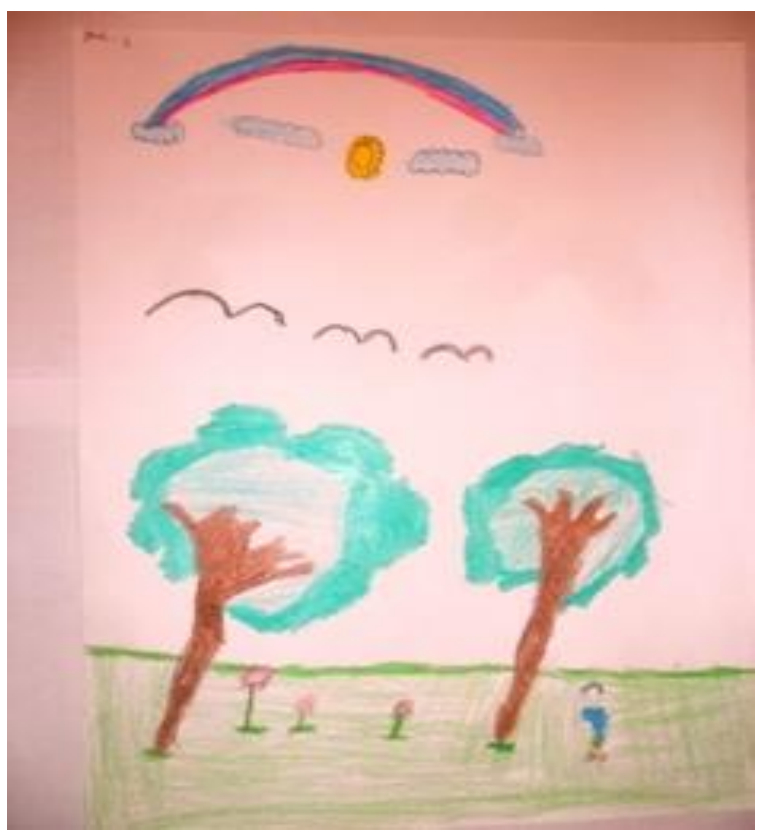

Figura 4: Representada por J. A. (6 anos)

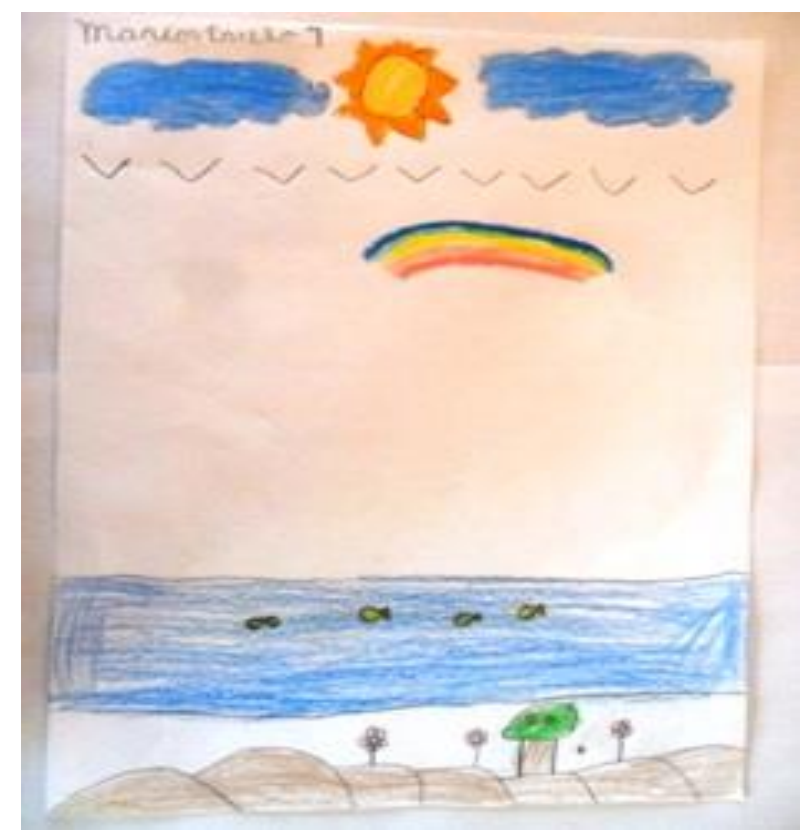

Figura 5: Representada por M. P. (7 anos)

Em resposta a letra da música "será que no futuro haverá flores?" Sim, a resposta nos desenhos é que haverá flores, assim como, a presença do homem se mostra presente neste futuro como parte da relação homem/natureza, como pode ser observado nos desenhos de J.O (figura 6), I.S (figura 7), A.U (figura 8) e A.N (figura 9). 


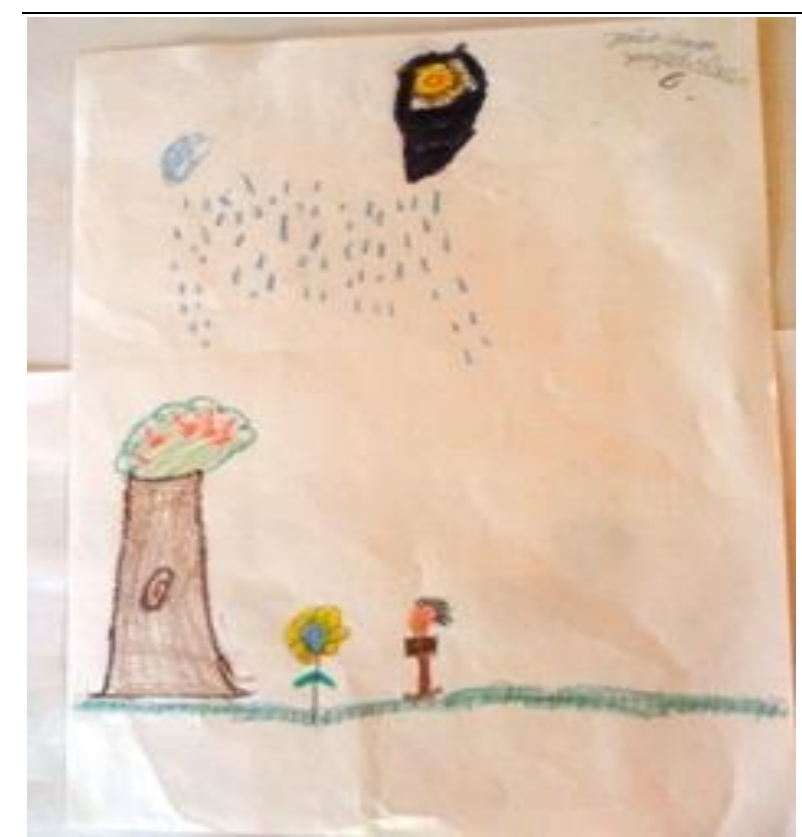

Figura 6: Representada por J. O. (6 anos)

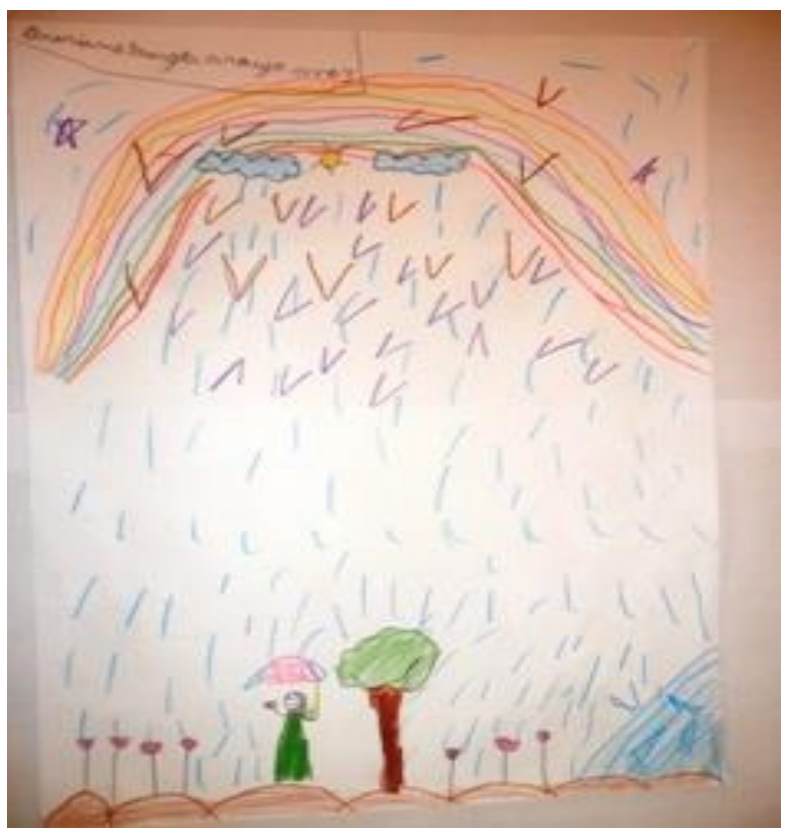

Figura 8: Representada por A. U. (9 anos)

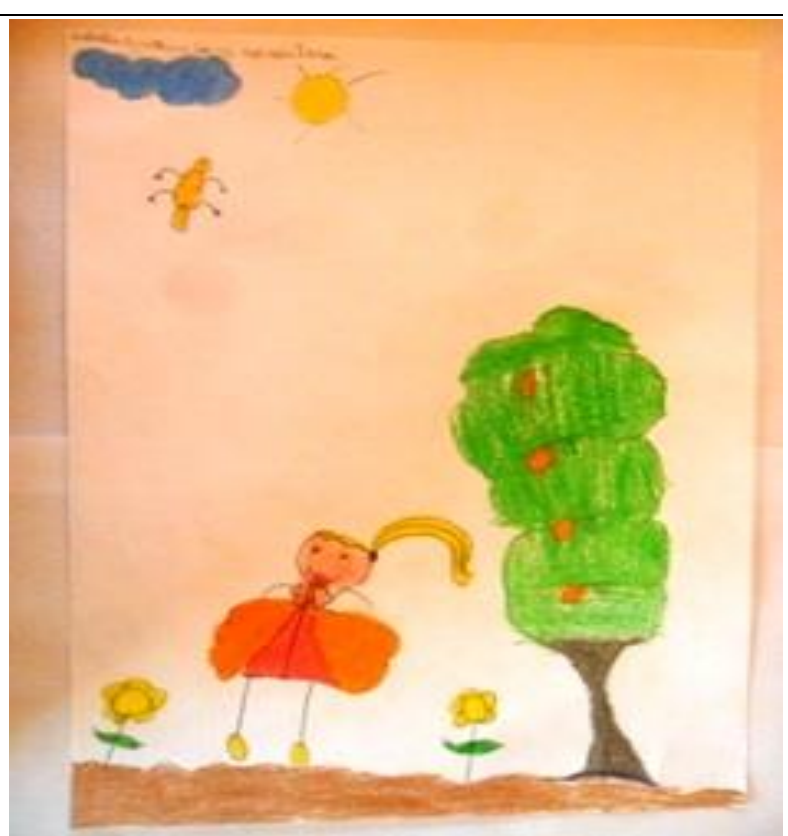

Figura 7: Representada por I. S. (6 anos)

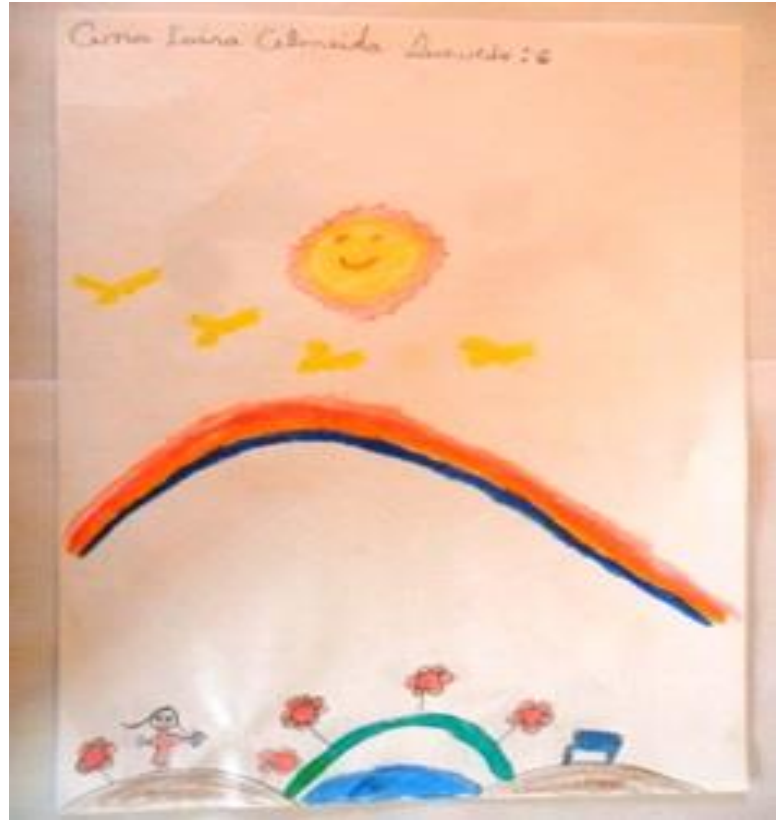

Figura 9: Representada por A. N. (6 anos)

Em contraposição, como mostra os desenhos: R.H (figura 10), J.O (figura 11), C.A (figura 12) e M.I (figura 13), que, não conseguem estabelecer a relação do homem com a natureza. Porém, concordam que, no futuro haverá flores. Estabelecem a relação de que os peixes estarão no mar. Tem a presença de elementos naturais como: árvores, rios, peixes e flores e traçam uma linha de base. 


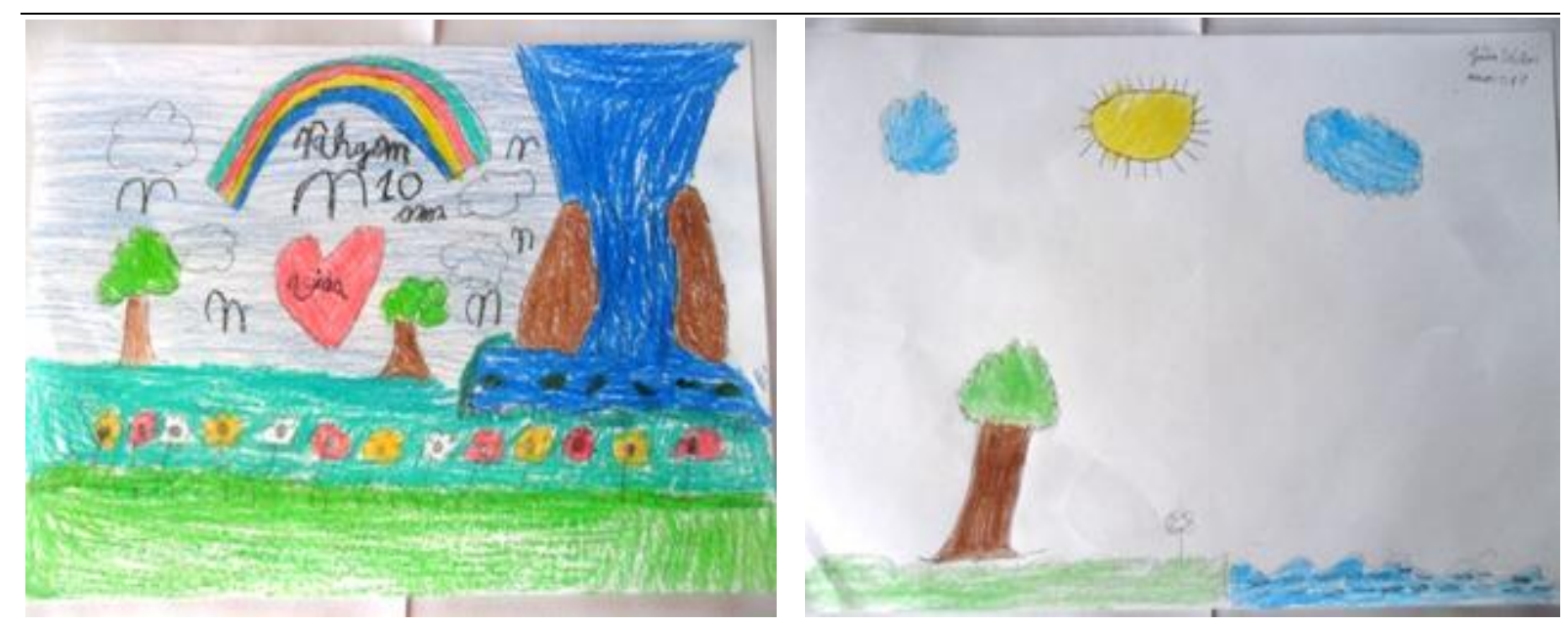

Figura 10: Representada por R. H. (10 anos) Figura 11: Representada por J. O. (11 anos)

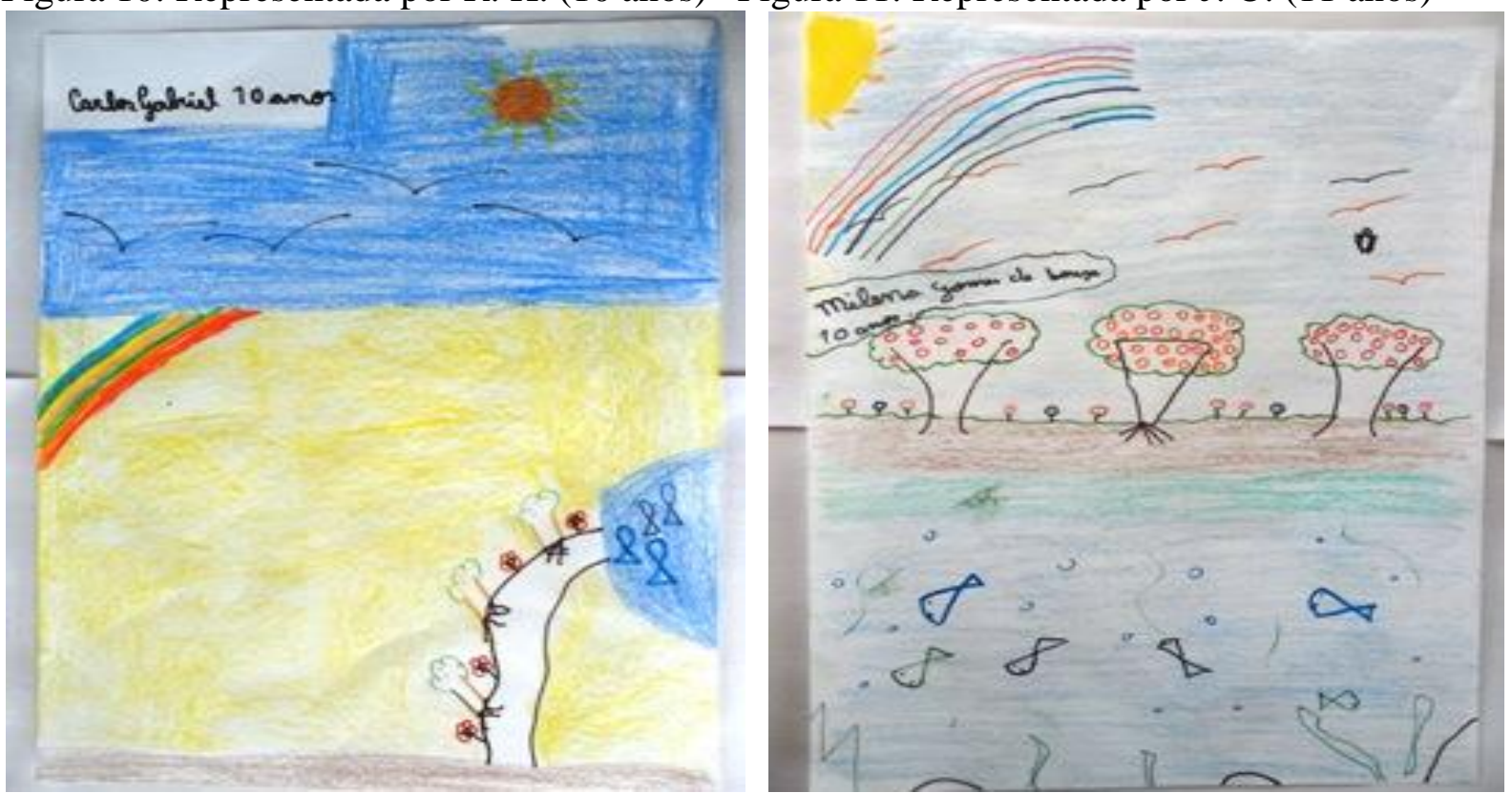

Figura 12: Representada por C. A. (10 anos)Figura 13: Representada por M. I. (10 anos)

$\mathrm{Na}$ interpretação das crianças, há em uma grande maioria dos desenhos, a presença do arco-íris como fazendo parte do futuro, como pode ser observado nas figuras: A.R (figura 14), G.U (figura 15), M.U (figura 16), D.A (figura 17),V.I (figura 18) e V.I (figura19).

Nos desenhos de G.U (figura 16), M.U (figura 17) e D.A (figura 18), a presença dos elementos naturais é fortemente marcada. Os desenhos apresentam o homem como parte da relação com a natureza. Em contraposição, os desenhos de A.R (figura15), V.I (figura 19) e V.I(figura 20), não apresentam o elemento humano, mas representam uma paisagem alegre e colorida. 


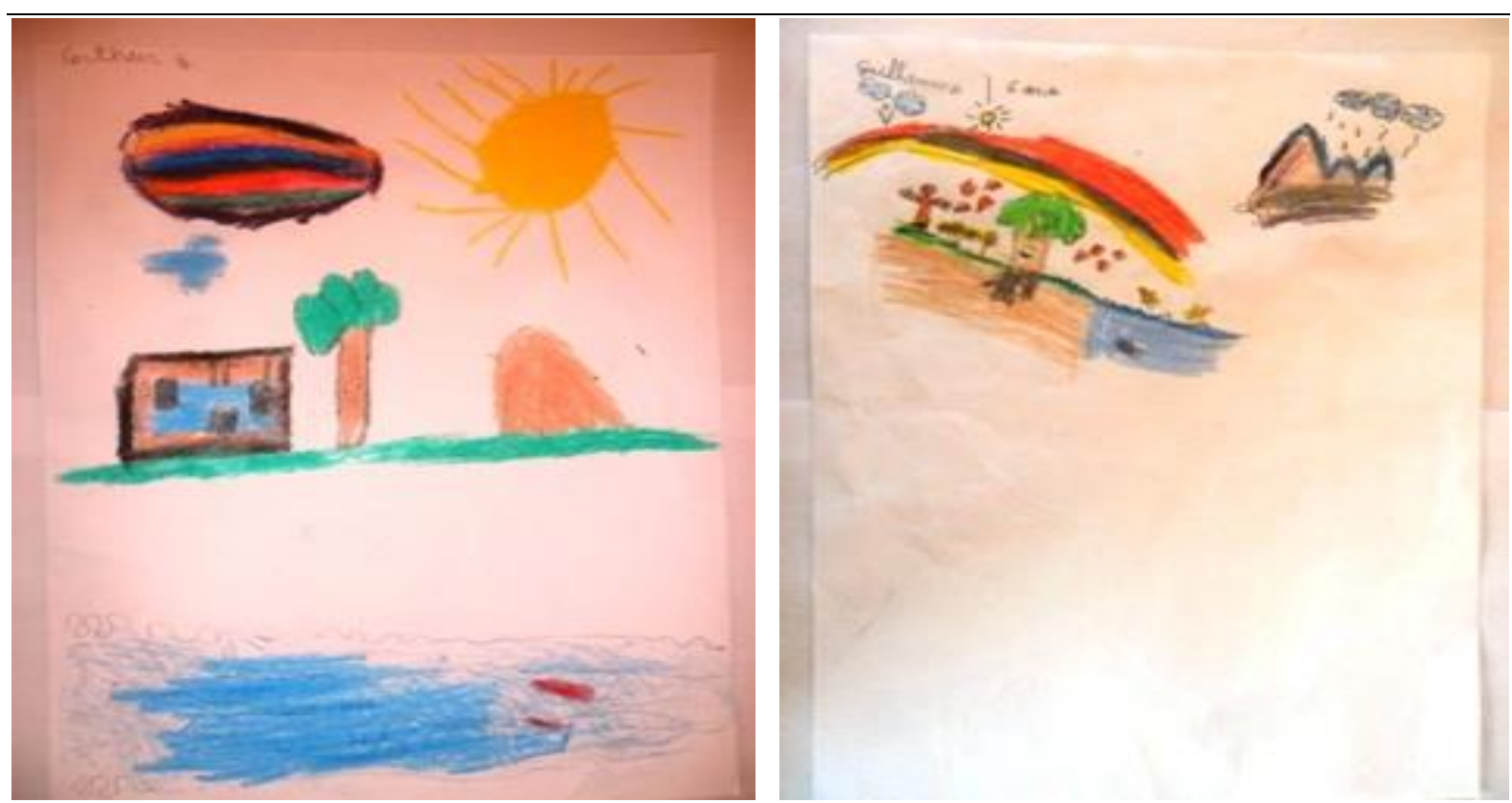

Figura 14: Representada por A.R(6 anos) Figura 15: Representada por G.U ( 6 anos)

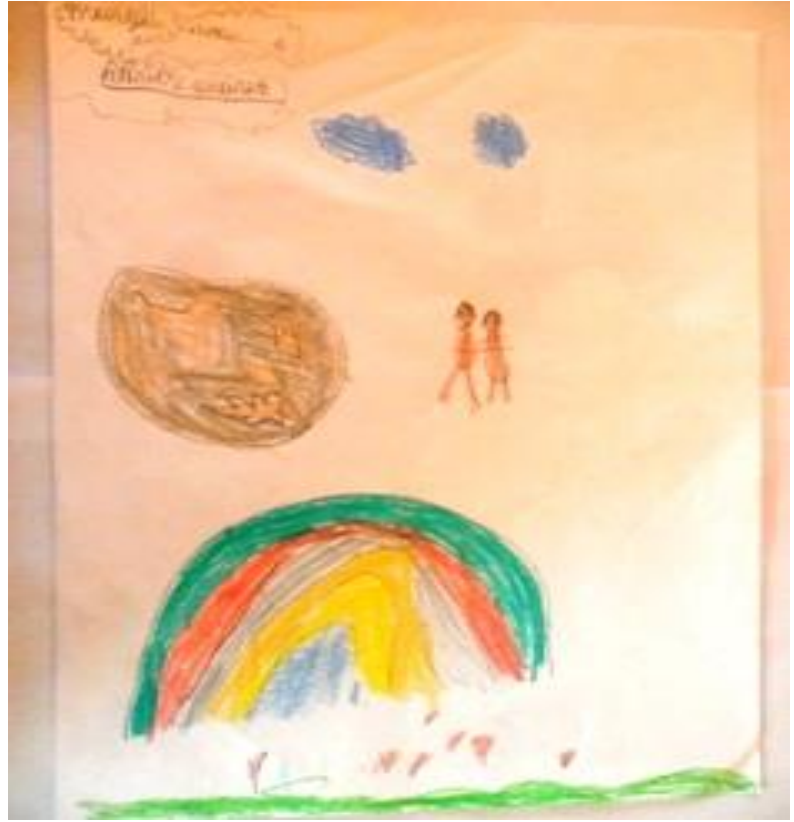

Figura 16: Representada por M.U(6 anos)

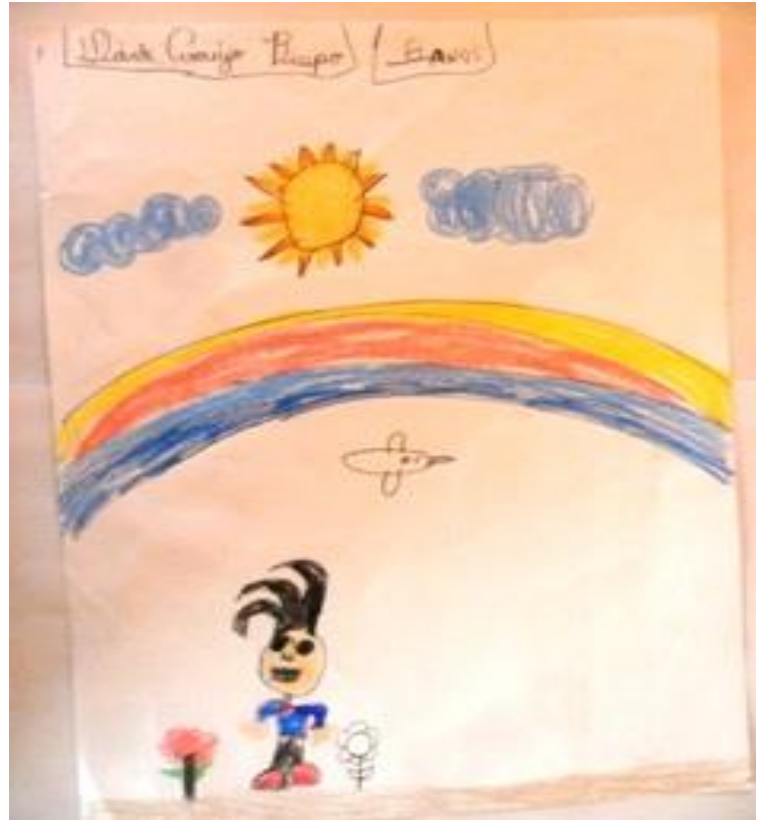

Figura 17:Representadapor D.A (6 anos) 


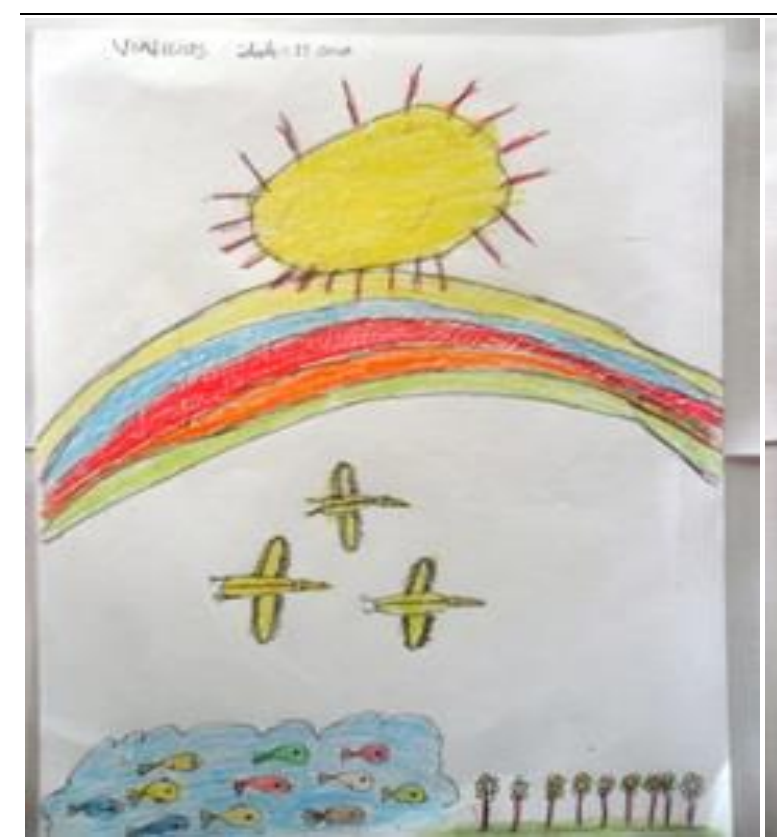

Figura18: Representada por V.I(11 anos)

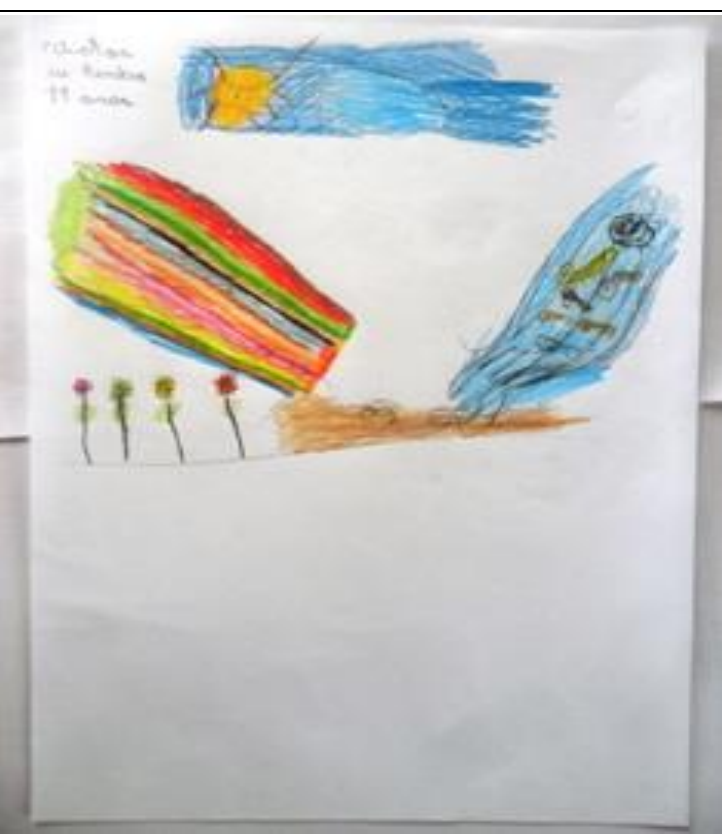

Figura19: Representada por V.I (11 anos)

Como podem ser observados os desenhos de J.O (figura 20) e M.A (figura 21), eles traçam uma linha de base. Ambos os desenhos representam um futuro alegre. $\mathrm{O}$ desenho de J.O apresenta elementos naturais como: árvores, rios e vegetação, em contraposição com o desenho do M.A que, além dos elementos naturais apresenta os animais como: peixes, tartarugas e pássaros que em resposta a letra da música estarão livres para voar. Ambos não estabelecem a relação homem/natureza.

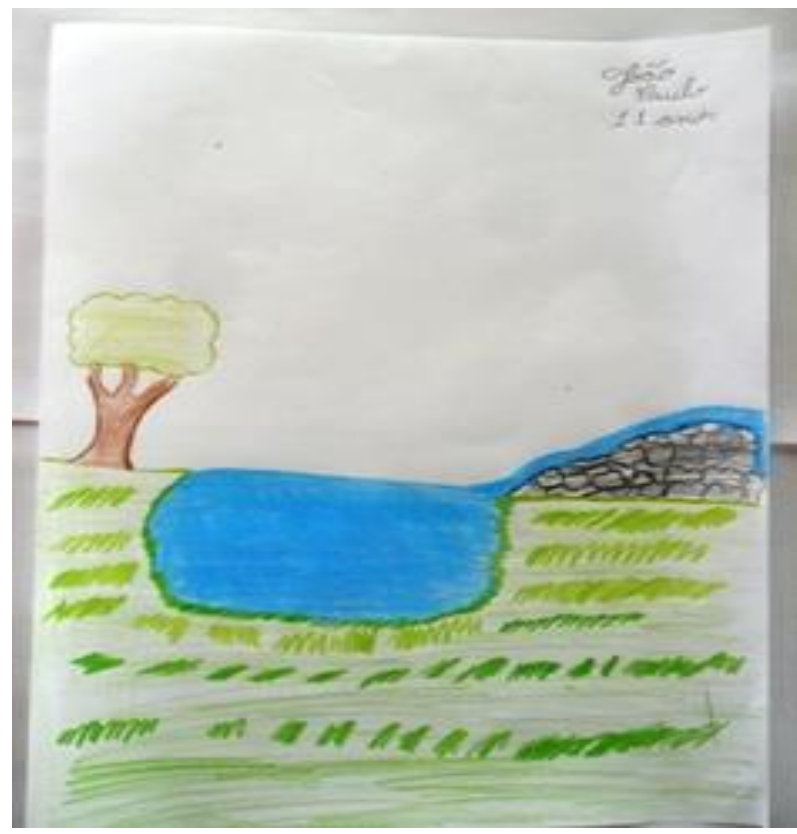

Figura 20: Representada por J.O(11 anos)

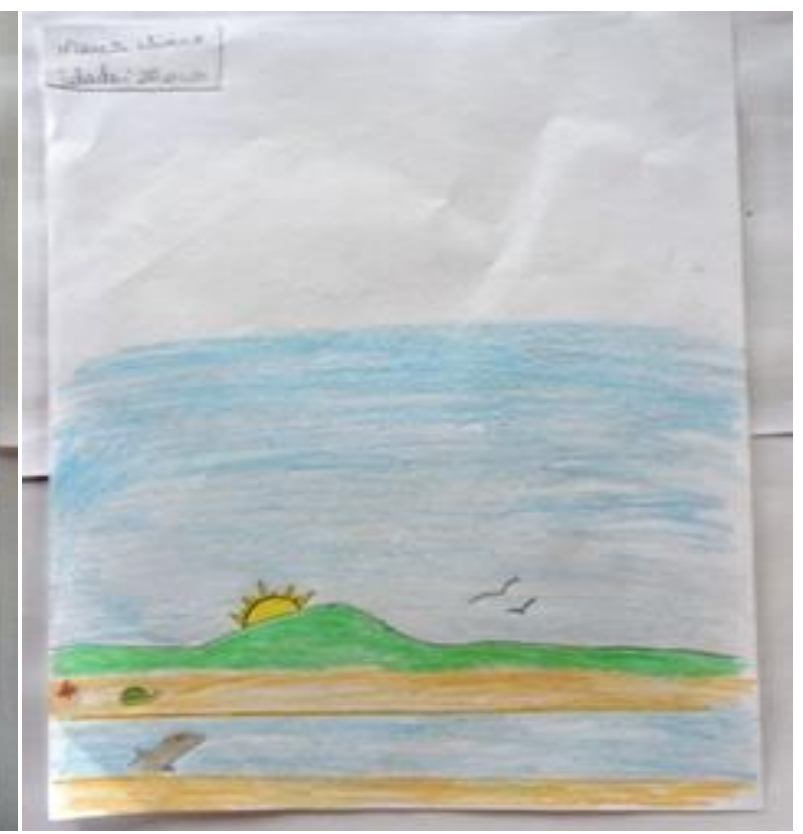

Figura 21: Representada por M.A(10 anos).

A letra da música "herdeiros do futuro", proporcionaa reflexão acerca do futuro, quanto a preservar e cuidar. Na interpretação de M.E (figura 22) e L.O (figura 23), os desenhos representam um futuro alegre, ambos são ricos em elementos naturais como: rios, peixes, sol, arco-íris dentre outros. 


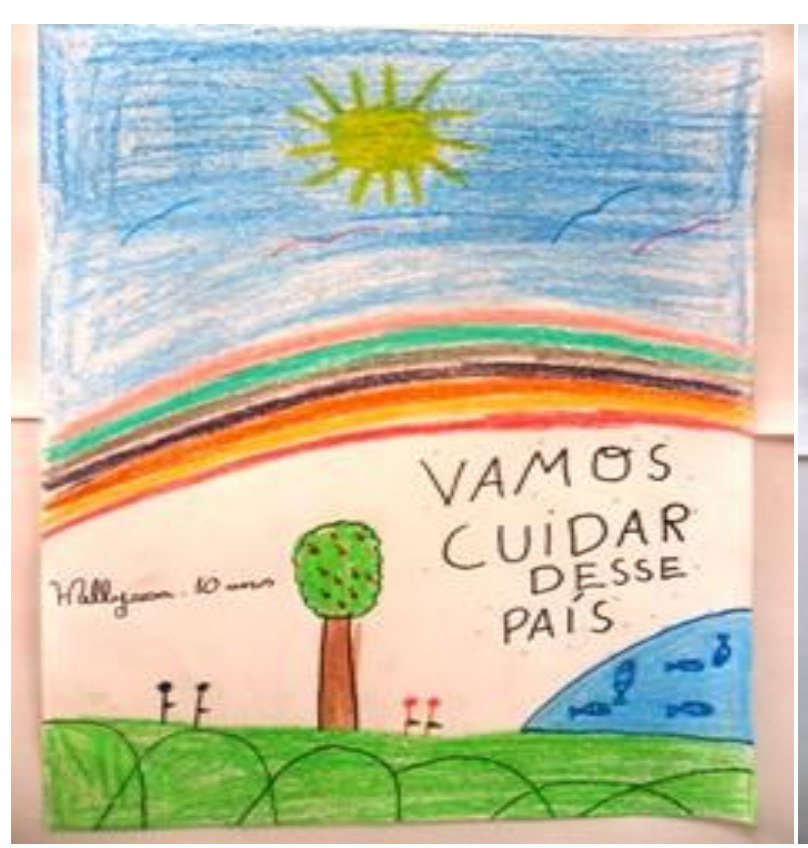

Figura 22: Representada por M.E(10 anos)

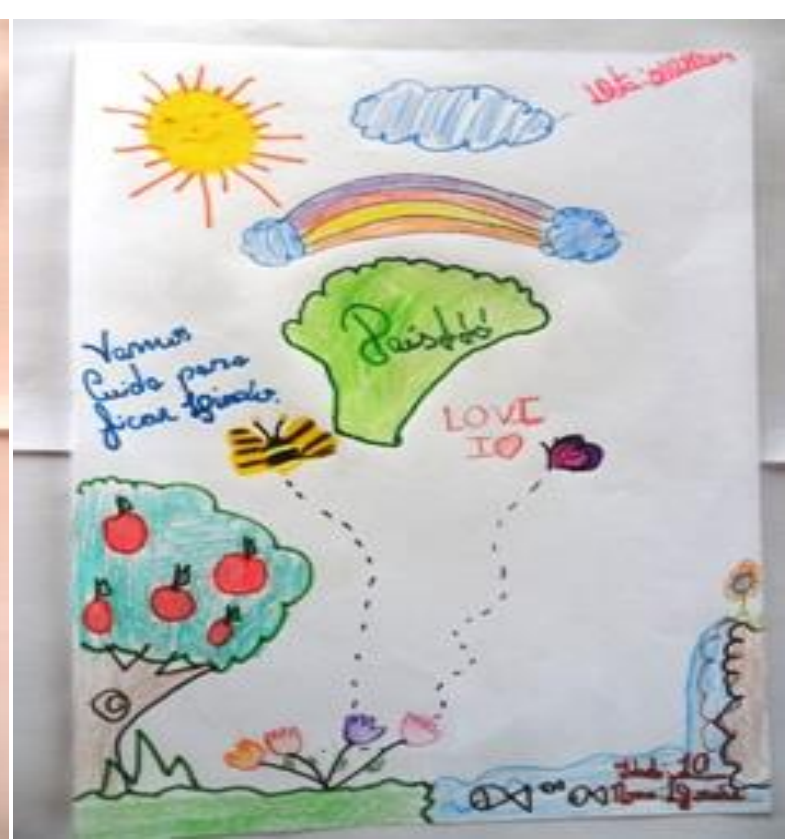

Figura 23:Representada por L.O (10 anos)

Os desenhos fazem um chamado a cuidar, para assim continuar produzindo frutos, porém, não associam o elemento humano como parte da paisagem. Traçam uma linha de base. Mas não apresentam interrelações entre homem e a paisagem.

Segundo Callai (2005, p. 229) o lugar da Geografia nas series iniciais é "aprender a pensar o espaço. E, para isso, é necessário aprender a ler o espaço." Durante a oficina apesar da pouca indicação dessa relação homem e paisagem, o processo de mediação do ensino permitiu que fizéssemos as relações e apresentações a importância que o ser humano possui na produção da paisagem, na mudança do lugar e nas transformações.

Conforme Santos (2016) trabalhar com desenhos é trabalhar com novas formas de ver, compreender e verificar as próprias idéias. O indivíduo, quando desenha, expressa uma visão e um raciocínio. O trabalho mostrou a potência que a atividade possui e o quão rico pode se tornar trabalhar com desenhos para compreender e ler o espaço.

\section{Consideraç̃es Finais}

O propósito do presente estudo foi o de analisar como a interpretação do desenho pode influenciar positivamente para uma melhor compreensão da paisagem ao ensino de Geografia nas series iniciais do ensino fundamental. A pesquisa foi desenvolvida com base na aplicação de uma oficina, onde, buscou-se com a música incentivar o aluno a desenvolver uma paisagem através do desenho, tendo assim, um maior interesse em demonstrar o que a paisagem representa em seu mundo.

Autores como Paganelli (1998), Peraya (1996) e Miranda (2005) apontam a relação histórica do desenho com a Geografia através da tradição dos croquis, esquemas gráficos de arranjos espaciais, esboços traçados no papel em observações de campo, como formas de estudo e registro das paisagens, dos lugares, das extensões, distribuições e localizações. Segundo Miranda (2005, p. 56) destaca que

O desenho nessa tradição geográfica envolve uma relação cognitiva e corporal com os elementos/objetos do espaço através do olhar-ver, do gesto, do traço, da atenção ao conjunto e aos detalhes, em um movimento do corpo 
e do pensamento, entre a observação e a apreensão de um todo em suas linhas gerais formando uma estrutura, a abstração e a análise, pelo isolamento de elementos selecionados, e a elaboração de uma síntese na composição do conjunto pelo traçado no papel.

O desenho revela muito mais que apenas uma ilustração é uma forma de expressar o que aluno apreendeu durante a aula e/ou oficina. O que está visível relvela e o que também não foi expresso em imagens é revelador. Os elementos presentes no desenho são portadores de uma linguagem e expressam aquilo que foi mais marcante para o aluno, mas também é fundamental perceber o que não foi expresso, não foi representado e portanto não foi percebido a ponto de se fazer presente. É o conhecimento adquirido durante a vida e seu cotidiano, que estará representado no desenho do aluno, são as conexões, as interrelações, as redes e as tecituras do processo de ensino-aprendizagem.

Quando o aluno faz um desenho ele tem que se libertar do aspecto sensorial da linguagem e transcrever em imagens. Utilizando seu conhecimento sobre o assunto, sua memória e imaginação para fazer o desenho. Assim, montando um contexto de imagens ligando um ao outro formando um só elemento.

Como este trabalho foi possível perceber que o desenho auxiliou o aluno na compreensão e na construção das relações de problematização propostas pelo conteúdo expresso pela música. Usando o desenho como recurso didático o professor estimula a criatividade do aluno e inclusive aumenta sua interação com a classe. $\mathrm{O}$ desenho é um recurso que traz consigo grande quantidade de informações que podem ser exploradas pelo professor, além de ser um recurso muito simples de ser trabalhado.

Cade vez mais temos necessidade de usar diferentes alternativas, estratégias, metodologias e recursos em sala de aula que busquem tornar as aulas de Geografia mais dinâmicas e criativas para garantir o interesse dos alunos, permitindo assim o melhor aprendizado de todos inclusive do próprio professor.

\section{Referências}

BRASIL. Secretaria de Educação Fundamental. Parâmetros curriculares nacionais: geografia / Secretaria de Educação Fundamental. Brasília: MEC/ SEF, 1998. p. 156.

CALLAI, Helena Copetti. Aprendendo a ler o mundo: a geografia nos anos iniciais do ensino fundamental. Caderno Cedes, Campinas, vol. 25, n. 66, p. 227-247, maio/ago. 2005. Disponível em http://www.cedes.unicamp.br Acesso em 30 de outubro de 2016.

O estudo do lugar como possibilidade de construção da identidade e pertencimento. VIII CONGRESSO LUSO-AFRO-BRASILEIRO DE CIÊNCIAS SOCIAIS COIMBRA 16, 17 E 18 DE SETEMBRO DE 2004, Coimbra Portugal, 2004. p. 10. Disponível em http://www.ces.uc.pt/lab2004/pdfs/HelenaCallai.pdf Acesso em 30 de outubro de 2016.

CARMO, Enedina Silva do; BOER, Noemi. Aprendizagem e desenvolvimento na perspectiva interacionista de Piaget, Vygotsky e Wallon. Artigo Enedina. Centro Universitário Franciscano (UNIFRA), Santa Maria, RS, Brasil, 2014. p. 10.Disponível em http://jne.unifra.br/artigos/4742.pdf Acesso em 30 de outubro de 2016. 
FARIA, Anália Rodrigues de. O desenvolvimento da criança e do adolescente segundo Piaget. In: O período pré-operacional e operacional concreto. São Paulo: Ed. ÁTICA, 2001. Cap. 3, pp. 48-56.

GIL, Antonio Carlos. Como Elaborar Projetos de Pesquisas. 5ª ed. São Paulo: Atlas, 2010.

HOLZER, Werther. Uma discussão fenomenológica sobre os conceitos de paisagem e lugar, Território e meio ambiente. Revista Território, ano II, nº 3, p. 77-85, jul./dez.1997.

MALANSKI, Lawrence Mayer. Geografia escolar e paisagem sonora. Revista RA'E GA 22, Curitiba, 2011. p. 252-273.

MIRANDA, Sérgio Luiz. O lugar do desenho e o desenho do lugar no ensino de geografia : contribuição para uma geografia escolar crítica. Tese de Doutoramento. Universidade Estadual Paulista - UNESP, Rio Claro : 2005.

PAGANELLI, Tomoko Iyda. Paisagem, uma decifração do espaço-tempo social: as representações da paisagem da cidade do Rio de Janeiro. Tese (Doutorado em Geografia) Faculdade de Filosofia, Letras e Ciências Humanas, Universidade de São Paulo, São Paulo, 1998

PERAYA, Daniel. Ler uma imagem. Tradução de Alain P. François. Educação \& Sociedade, Campinas, n. 56, CEDES, dezembro/1996, p. 502-505.

PIAGET, Jean. A construção do real na criança. Conclusão: A elaboração do universo. São Paulo, 2002. p. 357-363.

SANTOS, Clézio dos. O desenho do lugar: uma experiência da Geografia da infância na baixada fluminense. Revista Brasileira de Educação em Geografia, Campinas, v. 6, n. 11, p.185-207, jan./jun., $2016 . \quad$ Disponível em http://www.revistaedugeo.com.br/ojs/index.php/revistaedugeo/article/view/311/186 Acesso em 30 de outubro de 2016.

SCHIER, Raul A. Trajetórias do conceito de paisagem na geografia. Revista RA'E GA, Curitiba, n. 7, 2003. p. 79-85. Disponível em http://revistas.ufpr.br/raega/article/viewFile/3353/2689 Acesso em 30 de outubro de 2016.

SERPA, Angelo. Paisagem, lugar e região: perspectivas teórico-metodológicas para uma geografia humana dos espaços vividos. GEOUSP - espaço e tempo, São Paulo, $\mathrm{N}^{\circ} 33$, pp. 168- 185, 2013. Disponível em http://www.revistas.usp.br/geousp/article/view/743309/77952 Acesso em 30 de outu de 2016.

SILVA, Marcelo Marchioretto da. O uso da linguagem musical no ensino de geografia.Universidade Federal do Paraná. Curitiba, 2013. p. 81.Disponível em <http://www.educadores.diaadia.pr.gov.br/arquivos/File/abril2013/geografia_artigos/tcc_musi carecursopedagogico13.pdf> Acesso em: 29/08/2014. 
SOUZA, Natália Moreira de; WECHSLER, Amanda Muglia. Reflexões sobre a teoria piagetiana: o estágio operatório concreto. Cadernos de Educação: Ensino e Sociedade, Bebedouro-SP, $\quad 1 \quad$ (1): 134-150, 2014. $\quad$ Disponível em http://www.unifafibe.com.br/revistasonline/arquivos/cadernodeeducacao/sumario/31/0404201 4074217.pdf Acesso em 30 de outubro de 2016.

TORRES, Marcos Alberto; KOZEL, Salete. Paisagens sonoras: possíveis caminhos aos estudos culturais em geografia. Revista RA'E GA, Curitiba, n. 20, 2010. p. 123-132. Disponível em http://revistas.ufpr.br/raega/article/view/20616 Acesso em 30 de outubro de 2016. 